\title{
Bacterial Contamination of Equine Dentistry Equipment-Effect of Cleaning and Disinfection
}

\author{
Todd Alsing-Johansson ${ }^{1, *} \mathbb{C}$, Anja Pedersen ${ }^{1}$, Karin Bergström ${ }^{2}$, Susanna Sternberg-Lewerin ${ }^{3} \mathbb{C}$, Johanna Penell ${ }^{1}$ \\ and Anna Bergh ${ }^{1}$ (D) \\ 1 Department of Clinical Sciences, Swedish University of Agricultural Sciences, 75007 Uppsala, Sweden; \\ anja.pedersen@slu.se (A.P.); johanna.penell@slu.se (J.P.); Anna.Bergh@slu.se (A.B.) \\ 2 Department of Animal Health and Antimicrobial Strategies, National Veterinary Institute, 75189 Uppsala, \\ Sweden; karin.bergstrom@sva.se \\ 3 Department of Biomedical Sciences and Veterinary Public Health, Swedish University of Agricultural \\ Sciences, 75007 Uppsala, Sweden; susanna.sternberg-lewerin@slu.se \\ * Correspondence: todd.johansson@slu.se
}

Citation: Alsing-Johansson, T.;

Pedersen, A.; Bergström, K.;

Sternberg-Lewerin, S.; Penell, J.;

Bergh, A. Bacterial Contamination of Equine Dentistry Equipment-Effect of Cleaning and Disinfection. Animals 2021, 11, 2320. https://doi.org/ $10.3390 /$ ani11082320

Academic Editor: Teppei Kanda

Received: 29 June 2021

Accepted: 3 August 2021

Published: 5 August 2021

Publisher's Note: MDPI stays neutral with regard to jurisdictional claims in published maps and institutional affiliations.

Copyright: (c) 2021 by the authors. Licensee MDPI, Basel, Switzerland. This article is an open access article distributed under the terms and conditions of the Creative Commons Attribution (CC BY) license (https:// creativecommons.org/licenses/by/ $4.0 /)$.
Simple Summary: Some of the equipment used in equine dentistry is difficult to clean and disinfect. Since it is vital to avoid the spread of infections in equine healthcare it is important to develop practical and easy-to-follow methods for cleaning and disinfecting dental equipment. The aim of this study was to investigate hygiene in equine dentistry. Dental equipment and the head support, where horses rest their head during dental care, were sampled for the amount of bacteria between each patient before and after dental care as well as after cleaning and/or disinfecting. The amount of bacteria was, in general, high on dental equipment and the head support after dental procedures. Bacteria were found in different amounts on most of the dental equipment after cleaning or disinfecting, which indicates a risk for spreading infections when using the equipment. For the head support, cleaning and/or disinfecting generally resulted in a reduced amount of bacteria, indicating a lowered risk for spreading infections. There is a great need for evidence-based guidelines on hygiene in equine dentistry to decrease the risk of transmitting infections between patients, facilities, and stables.

Abstract: Equine dentistry has developed immensely and human dental equipment, such as handpieces, are often used. Measures to avoid the spread of infectious microorganisms are important, but this is challenging since handpieces are difficult to decontaminate. Thus, it is necessary to develop effective IPC measures in equine dentistry. The aim of this study was to contribute to the evidence needed for future evidence-based guidelines on IPC by investigating hygiene in equine dentistry. Used handpieces and dummies (i.e., handpieces not used during dental procedure, reflecting environmental bacterial contamination) and the head support were sampled each day before the first patient, for each patient after treatment, and after decontamination. All equipment was sampled with 3M TM Swab Samplers and the head support additionally sampled with dip slides. After dental procedures, the detected bacterial load was often high on used handpieces, dummies, and the head support. After decontamination, handpieces did not meet the criteria for high-level disinfected equipment. In all but one case decontamination of the head support resulted in a lowered bacterial load. There is a great need for evidence-based guidelines on hygiene in equine dentistry, including IPC measures, to decrease the risk of spreading infectious microorganisms between patients, facilities, and stables.

Keywords: infection prevention and control; biosecurity; contamination; dental handpiece

\section{Introduction}

Equine dental care is carried out at veterinary hospitals, clinics, and mobile practices. Equine dental health is a rapidly growing area in veterinary clinical practice. The frequency of treatments and types of dental procedures have increased during the last decades. The advancement of equine dental care in Sweden has made it common to use human 
dental equipment both for routine and advanced procedures. Handpieces, e.g., lowspeed handpieces (LSH), surgical low-speed handpieces ( $\mathrm{SH})$, and high-speed handpieces (HSH), are used for both simple procedures, such as decreasing enamel ridges, and more advanced procedures, such as endodontic treatments. Even though protocols for cleaning, disinfecting, and sterilizing handpieces are in place for use in human dentistry there is a lack of knowledge regarding the cleaning, disinfecting, and sterilizing routines needed to ensure low risk for spreading infectious microorganisms between equine patients.

Measures to avoid the spread of infectious microorganisms between patients, and to staff, is common clinical practice in both human and veterinary medicine. This aspect of equine dentistry is challenging as handpieces are difficult to decontaminate, especially in mobile practices. Thus, there is a great need for effective infection prevention and control (IPC) measures in equine dentistry. The advanced dental procedures also entail a risk for transmission of infectious microorganisms between equine patients. For example, in a North American study, respiratory pathogens such as Equine herpes virus 1 and 4 (EHV-1, EHV-4), Equine influenza virus (EIV), Equine rhinitis B virus (ERBV), and/or methicillin-resistant Staphylococcus aureus (MRSA) were detected in 22\% of healthy horses presented for routine dental care [1]. Furthermore, bacterial contamination of external and internal surfaces of handpieces has been shown after human dental procedures [2-5]. In addition, a higher degree of contamination of the environment and, thereby, an increased risk for patients when using high-speed devices, compared to using low-speed devices, has been shown [6,7]. There are, to our knowledge, no studies on contamination of handpieces or the surrounding environment in equine dentistry.

Based on use and hygiene, requirements for medical equipment, including dental handpieces, are categorized as non-critical, semi-critical, and critical [8]. The different categories require different levels of cleaning, disinfecting, and sterilizing (see Table 1). Handpieces are classified as semi-critical equipment, as long as they are used for nonsterile procedures, under Swedish and US hygiene guidelines for human dentistry as well as Swedish guidelines on IPC in equine healthcare and in small animal dentistry literature [8-11]. There is, however, no international consensus on criteria for the expected cleanliness for high-level disinfected equipment. Guidelines in human dentistry on how to clean, disinfect, and sterilize handpieces differ between countries. Several studies on human dental equipment demonstrate the challenges to meet criteria for both high-level disinfected and sterile equipment for handpieces. Surface disinfection of the external surface of handpieces resulted in failure to meet the criteria for high-level disinfection [12]. In another study, one of four cleaning devices intended for handpieces, the washer-disinfector (WD), provided an acceptable test result [13]. In one study, type $\mathrm{N}$ steam sterilizers failed to provide sterile handpieces whilst type B steam sterilizers provided sterile handpieces [14].

Table 1. Presentation of categorization of dental equipment in human dentistry, area of use, microbial definition according to Swedish guidelines and standards, and the level of cleaning, disinfecting, and sterilizing needed, according to Swedish guidelines.

\begin{tabular}{|c|c|c|c|c|c|}
\hline Category & Use & $\begin{array}{c}\text { Example of } \\
\text { Equipment Used } \\
\text { in Human } \\
\text { Dentistry }\end{array}$ & $\begin{array}{l}\text { Example of } \\
\text { Equipment } \\
\text { Used in Equine } \\
\text { Dentistry }\end{array}$ & $\begin{array}{c}\text { Microbial } \\
\text { Definition of } \\
\text { Category in } \\
\text { Swedish } \\
\text { Guidelines in } \\
\text { Human Dentistry }\end{array}$ & $\begin{array}{l}\text { Level of Cleaning, } \\
\text { Disinfecting, and } \\
\text { Sterilizing in Swedish } \\
\text { Guidelines in Human } \\
\text { Dentistry }\end{array}$ \\
\hline Non-critical & $\begin{array}{l}\text { In contact with } \\
\text { intact skin }\end{array}$ & Spatulas & Mouth specula & Visibly clean [9] & $\begin{array}{l}\text { Cleaning if not } \\
\text { contaminated; if } \\
\text { contaminated, cleaning } \\
\text { and disinfecting in a } \\
\text { washer-disinfector (WD) } \\
\text { or manual cleaning } \\
\text { followed by chemical } \\
\text { disinfecting [9] }\end{array}$ \\
\hline
\end{tabular}


Table 1. Cont

\begin{tabular}{|c|c|c|c|c|c|}
\hline Category & Use & $\begin{array}{c}\text { Example of } \\
\text { Equipment Used } \\
\text { in Human } \\
\text { Dentistry }\end{array}$ & $\begin{array}{l}\text { Example of } \\
\text { Equipment } \\
\text { Used in Equine } \\
\text { Dentistry }\end{array}$ & $\begin{array}{c}\text { Microbial } \\
\text { Definition of } \\
\text { Category in } \\
\text { Swedish } \\
\text { Guidelines in } \\
\text { Human Dentistry }\end{array}$ & $\begin{array}{l}\text { Level of Cleaning, } \\
\text { Disinfecting, and } \\
\text { Sterilizing in Swedish } \\
\text { Guidelines in Human } \\
\text { Dentistry }\end{array}$ \\
\hline Semi-critical & $\begin{array}{l}\text { In contact with } \\
\text { mucus membranes, } \\
\text { but not } \\
\text { penetrating sterile } \\
\text { tissue }\end{array}$ & Handpieces & $\begin{array}{l}\text { Drills, burrs and } \\
\text { handpieces used } \\
\text { when not } \\
\text { penetrating pulp, } \\
\text { e.g., } \\
\text { decreasing enamel } \\
\text { ridges }\end{array}$ & $\begin{array}{l}\text { Free from } \\
\text { pathogenic micro- } \\
\text { organisms and less } \\
\text { than one } \\
\text { microorganism on } \\
1000 \\
\text { handpieces [9] }\end{array}$ & $\begin{array}{l}\text { Cleaning and } \\
\text { disinfecting } \\
\text { in a WD [9] }\end{array}$ \\
\hline Semi-critical & $\begin{array}{l}\text { In contact with } \\
\text { mucus membranes, } \\
\text { but not } \\
\text { penetrating sterile } \\
\text { tissue }\end{array}$ & Compresses & Compresses & $\begin{array}{l}\text { Free from } \\
\text { pathogenic micro- } \\
\text { organisms and } \\
\text { occurrence } \\
\text { of occasional vital } \\
\text { micro- } \\
\text { organisms [15] }\end{array}$ & $\begin{array}{l}\text { Cleaning and } \\
\text { disinfecting if the } \\
\text { equipment is made for } \\
\text { reuse }\end{array}$ \\
\hline Critical & $\begin{array}{l}\text { In contact with } \\
\text { sterile tissue }\end{array}$ & $\begin{array}{l}\text { Surgical } \\
\text { instruments, like } \\
\text { extraction forceps }\end{array}$ & $\begin{array}{c}\text { Drills, burrs, } \\
\text { handpieces, } \\
\text { and other } \\
\text { instruments used } \\
\text { when penetrating } \\
\text { pulp, e.g., } \\
\text { endodontic } \\
\text { treatments }\end{array}$ & $\begin{array}{l}\text { Free from living } \\
\text { micro- } \\
\text { organisms/less } \\
\text { than one } \\
\text { microorganism on } \\
1,000,000 \\
\text { handpieces }[15,16]\end{array}$ & $\begin{array}{l}\text { Cleaning and } \\
\text { disinfecting in } \\
\text { a WD followed by } \\
\text { sterilizing } \\
\text { in a B-autoclave [9] }\end{array}$ \\
\hline
\end{tabular}

According to Pusterla et al. [1], equine dental equipment used for routine dental procedures, not expected to expose the pulp (i.e., semi-critical equipment), is rarely cleaned and disinfected between patients. Even though the equipment used for routine dental procedures can differ between countries, the conditions for cleaning procedures and risk of spreading infections can be assumed to be comparable. Moreover, IPC routines for equipment used in equine dentistry are not listed in the syllabus of equine dentistry courses in Sweden and in the European specialist program in equine dentistry $[17,18]$. In our experience, a commonly used decontamination method for handpieces in equine dentistry is surface disinfection with an intermediate disinfectant (a disinfectant with effect on most vegetative bacteria, some mycobacteria, some fungi, some enveloped and non-enveloped viruses [19]) without previous cleaning. However, no decontamination procedure in equine dentistry has yet been evaluated or published. Guidelines for IPC procedures in equine dental practice, based on solid data, are needed.

The overall aim of this study was to contribute to the evidence needed for future guidelines on IPC procedures for equine dentistry by investigating hygiene in equine dentistry, specifically by:

(1) assessing the bacterial load on handpieces and the patient environment during equine dental care;

(2) assessing if manual cleaning of handpieces with detergent or disinfection with surface disinfection is sufficient to meet the Swedish criteria for high-level disinfected equipment; and

(3) determining the bacterial load on the immediate surroundings after surface disinfection, or cleaning followed by surface disinfection. 


\section{Materials and Methods}

The study was carried out in the dental practice of a veterinary hospital during the autumn of 2020. The veterinary hospital's patient load consists of approximately 9000 patients per year and approximately 500 of them are dental patients. Sampling was carried out during two working days, with a total of 11 horses submitted for dental care.

\subsection{Sampling}

Equipment and surfaces to be sampled for bacterial load were selected based on a pilot study carried out in the dental practice of another veterinary hospital (for details from the pilot study see Table S1: Bacterial load pilot study). The veterinary hospital's patient load consists of approximately 5000 patients per year and approximately 500 of them are dental patients. Based on the pilot results, sampling of handpieces and the head support was standardized (for details about sampling methods tested, see Table S2: Sampling methods tested). The sampling surfaces of the equipment are illustrated in Figure 1 and the sampling protocol is illustrated in Figure 2. Make and model of used handpieces can be found in the figure text in Figure 2.

Handpieces were sampled with $3 \mathrm{M}^{\mathrm{TM}}$ Swab Samplers (3M ${ }^{\mathrm{TM}}$ Swab Sampler, Saint Paul, Minnesota, USA) with letheen broth, an already established method in the food industry for control of hygiene [20]. The 3M ${ }^{\mathrm{TM}}$ Swab Samplers Method was modified to enable sampling of the different surfaces LSH, $\mathrm{SH}$, and $\mathrm{HSH}$, see Table 2 [21]. All samplings with $3 \mathrm{M}^{\mathrm{TM}}$ Swab Samplers were carried out by the second author and the first author held the handpieces, wearing non-sterile nitrile gloves, during sampling. The samples were then analyzed for total aerobic colony count (ACC).

The samples from the head support were also analyzed for total ACC, using two sampling methods; $3 \mathrm{M}^{\mathrm{TM}}$ Swab Samplers with letheen broth (both study days) and dip slides (Envirocheck ${ }^{\circledR}$ Dip Slide Disinfection Control (DC), $9,4 \mathrm{~cm}^{2}$, Orange, USA) with TSA agar/TSA agar with a neutralizer, neutralizing several disinfectants (one of the study days). A particular $10 \times 10 \mathrm{~cm}$ surface of the head support, a cushioned device supporting part of the horse's lower jaw, was repeatedly swabbed at each sampling with the 3M ${ }^{\text {TM }}$ Swab Samplers Method, see Table 2 [21]. Also, an adjacent specified surface of the head support was sampled with dip slides. The surface chosen for sampling can be contaminated by fluid from the mouth during dental examination and treatment. The dip slide was pressed firmly to the surface for $15 \mathrm{~s}$, then turned over and the opposite side of the slide was pressed against the adjacent surface for another $15 \mathrm{~s}$ [22]. All sampling with dip slides was carried out by the first author.

For each sampling day and sampling method, one or two negative controls (unexposed dip slide and swab sampler) were applied. The controls were put in the dental care room just before sampling started for the day, approximately $10 \mathrm{~min}$ before the day's first patient, and the controls were stored in the room until the gathering of sampling material after the last sampling of the day. 


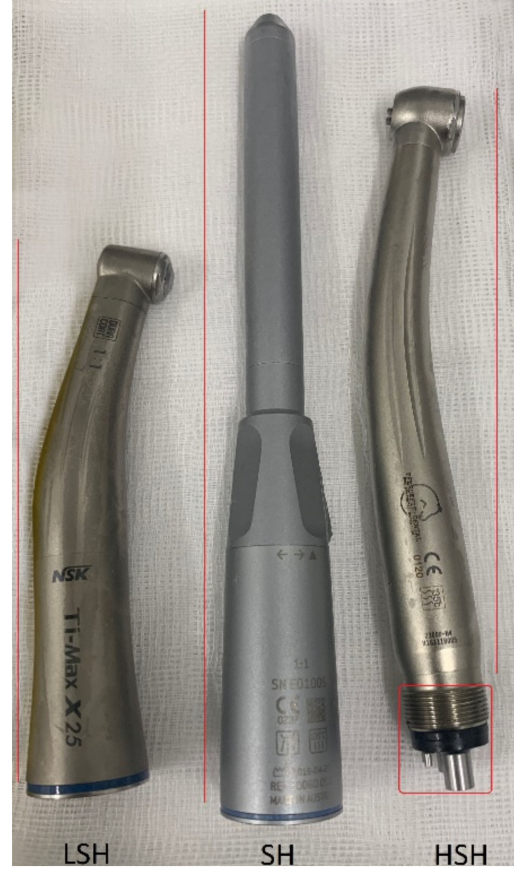

(a)

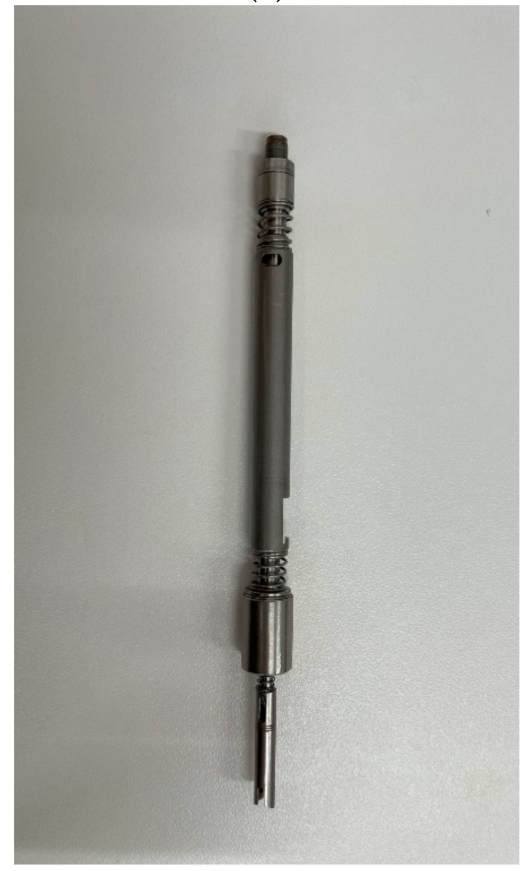

(c)

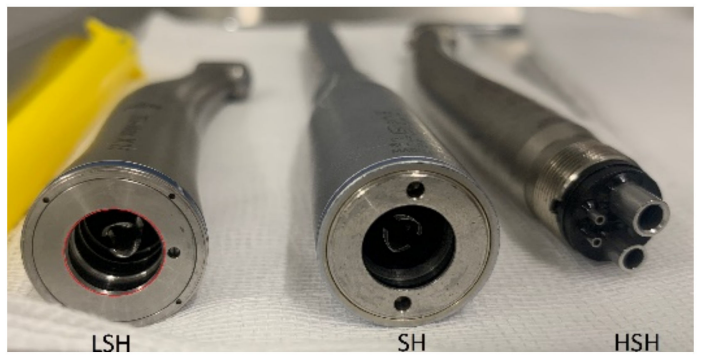

(b)

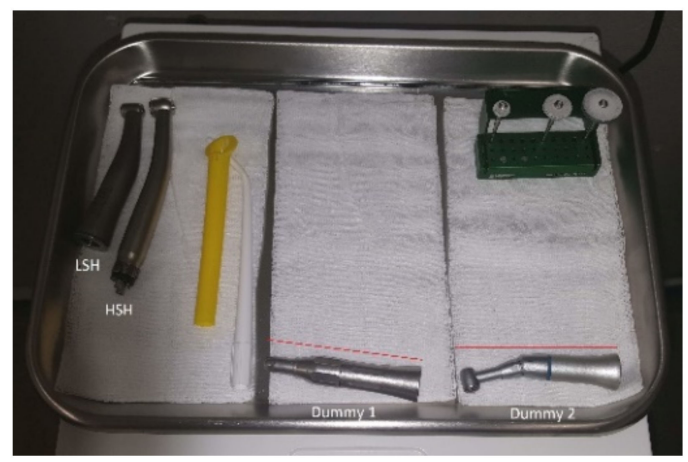

(d)

Figure 1. (a) Handpieces used for dental procedures in the study. LSH = Low-speed handpiece; SH = Surgical low-speed handpiece; and HSH = High-speed handpiece. Red lines indicate the external surface sampled of LSH, SH, and HSH. The red rectangle indicates the coupling surface sampled on HSH. (b) Handpieces used for dental procedures in the study. The red circle indicates the coupling of which the first $0.5 \mathrm{~cm}$ was sampled in LSH. (c) Shaft of SH; the red line indicates the surface sampled. (d) Some of the dental devices used in the study. The red lines indicate the external surface sampled on dummy 1 and 2 . 


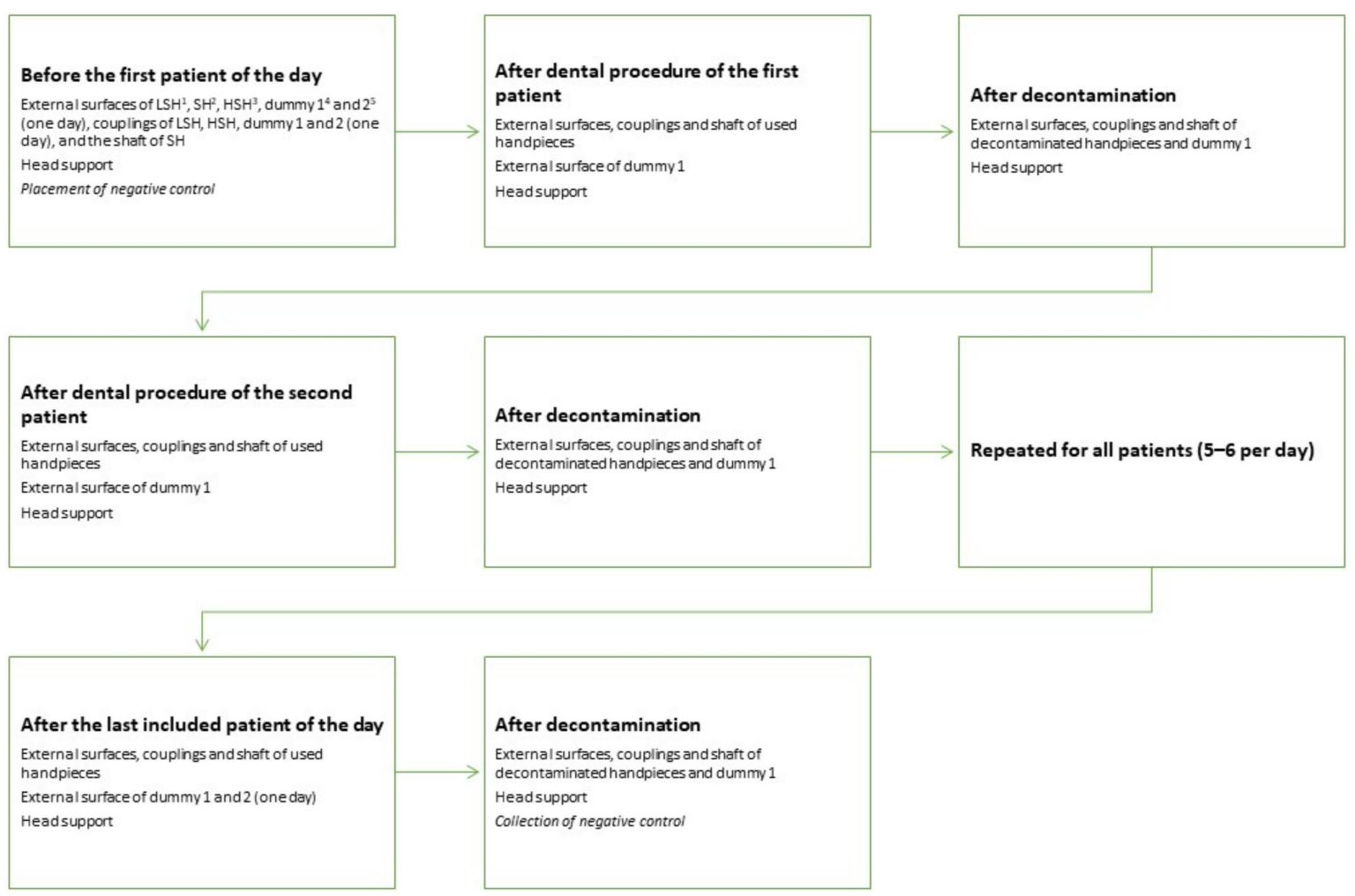

Figure 2. Sampling schedule for the equipment. For assessment of environmental contamination one or two extra LSH (called dummy 1 and 2) and the head support were sampled. The dummies were not used during dental procedure, but consisted of one or two extra handpieces placed close by if needed during the procedure (approximately $70 \mathrm{~cm}$ from the patient's oral cavity). Sampling after dental procedure was carried out within $5 \mathrm{~min}$ after the dental procedure was finished and no equipment was rinsed or wiped off before sampling. ${ }^{1}$ NSK Ti-Max X25, ${ }^{2}$ W\&H S-15, ${ }^{3}$ Pferdefit-Dental Eco high speed SEA-F4-1-P DEN 1101, ${ }^{4}$ NSK FX 65, and ${ }^{5}$ NSK NAC-EC.

Table 2. Description of sampling methods for handpieces and the head support.

\begin{tabular}{|c|c|c|c|c|}
\hline Sampling Surface & Sampling Method & $\begin{array}{l}\text { Description of } \\
\text { Method }\end{array}$ & $\begin{array}{c}\text { Parallel Sampling } \\
\text { Method }\end{array}$ & $\begin{array}{l}\text { Description of } \\
\text { Parallel Method }\end{array}$ \\
\hline $\begin{array}{c}\text { External surface } \\
\mathrm{LSH}^{1} / \mathrm{SH}^{2} / \mathrm{HSH}^{3} / \\
\text { dummies }\end{array}$ & $\begin{array}{l}\text { Modified swab } \\
\text { sampler method } \\
\text { (MSS) }\end{array}$ & $\begin{array}{c}\text { Swabbed once, } \\
\text { specification of surfaces } \\
\text { (see Figure } 1)\end{array}$ & $\mathrm{NA}^{4}$ & NA \\
\hline $\begin{array}{l}\text { Coupling LSH/ } \\
\text { dummies }\end{array}$ & MSS & $\begin{array}{l}\text { Swab rotated } 360^{\circ} \text { three } \\
\text { times, swabbing } \\
\text { possible } 0,5 \mathrm{~cm} \text { into the } \\
\text { tunnel } \\
\text { (see Figure } 1 \text { ) }\end{array}$ & NA & NA \\
\hline Shaft SH & MSS & $\begin{array}{l}\text { Shaft swabbed once } \\
\quad(\text { see Figure } 1)\end{array}$ & NA & NA \\
\hline Coupling HSH & MSS & $\begin{array}{l}\text { Swab rotated } 360^{\circ} \text { three } \\
\text { times (see Figure } 1 \text { ) }\end{array}$ & NA & NA \\
\hline Head support & $\begin{array}{l}\text { Swab sampler } \\
\text { method [21] }\end{array}$ & $\begin{array}{l}\text { Specified, } 10 \times 10 \mathrm{~cm} \\
\text { surface. Swab rubbed } \\
\text { three times over area, } \\
\text { changing direction, first } \\
\text { by } 90^{\circ} \\
\text { then by } 45^{\circ} .\end{array}$ & Dip slide & $\begin{array}{l}\text { Pressed against surface } \\
15 \mathrm{~s} \text {, turned and } \\
\text { pressed } 15 \mathrm{~s} \text { against an } \\
\text { adjacent surface }\end{array}$ \\
\hline
\end{tabular}

${ }^{1}$ Low-speed handpiece. ${ }^{2}$ Surgical low-speed handpiece. ${ }^{3}$ High-speed handpiece. ${ }^{4}$ Not applicable. The swab was not put back in the tube between the three swabbings. 


\subsection{Cleaning and Disinfecting Methods}

Five protocols for cleaning and disinfecting handpieces and the head support were used (for details see Table 3). Protocols 1 and 2 consisted of the veterinary hospital's own protocol for surface disinfection with an intermediate disinfectant of handpieces and the head support. Protocol 3 consisted of manual cleaning of LSH and HSH and protocol 4 consisted of manual cleaning of SH. Protocol 5 consisted of manual cleaning of the head support followed by surface disinfecting with an intermediate disinfectant. LSH and SH were lubricated after every cleaning or disinfecting with a lubricant (PANA SPRAY Plus, NSK / Nakanishi inc., Kanuma, Japan) containing ester oil, ethanol butane, and propane. The HSH was lubricated using lubricating oil (MD-30 Advantage Dental Handpiece Oil MD-30, iM3, Sidney, Australia) containing synthetic hydrocarbon oil and ester oil after the last patient of the day. All handpieces were put back, out in the open, on a metal tray adjacent to the patient after cleaning or disinfecting and lubricating. The veterinary technician and the first author carried out every other cleaning or disinfection and lubrication of handpieces and the head support. During the period of sampling the dental care room and dental equipment were used three days a week. When protocols 1 and 2 were used, the dental care room and equipment had been unused for four days and when protocols 3-5 were used the dental care room and the dental equipment were used the day before.

Table 3. Protocols used for cleaning and disinfection of handpieces and the head support.

\begin{tabular}{|c|c|c|c|}
\hline Protocol & Equipment & $\begin{array}{c}\text { Cleaning and } \\
\text { Disinfecting Substance }\end{array}$ & Description of Cleaning and Disinfecting Methods \\
\hline 1 & $\begin{array}{l}\mathrm{LSH}^{1}, \mathrm{SH}^{2} \\
\text { and } \mathrm{HSH}^{3}\end{array}$ & $\mathrm{LD}^{4}$ & $\begin{array}{l}\text { Surface disinfection of external surfaces, including } \\
\text { external surface of couplings, by rubbing with disinfection } \\
\text { wipes (Wet Wipe Triamin Disinfection, Wet Wipes A/S, } \\
\text { Vallensbæk, Denmark) until visibly clean for } \geq 12 \mathrm{~s} \text {. }\end{array}$ \\
\hline 2 & Head support & $\mathrm{LD}+\mathrm{EPT}^{5} / \mathrm{LD}+\mathrm{EIT}^{6}$ & $\begin{array}{l}\text { Surface disinfection by rubbing with disinfection wipes } \\
\text { until visibly clean for } \geq 15-\mathrm{s} \text {, followed by spraying a } \\
\text { surface disinfectant (Dax } 75+\text {, KiiltoClean AB, Täby, } \\
\text { Sweden or LiV72+, Clemondo, Helsingborg, Sweden) } \\
\text { and rubbing the surface for } \geq 25 \text { s until dry and thereafter } \\
\text { spraying surface disinfectant on the surface to air-dry. }\end{array}$ \\
\hline 3 & LSH and HSH & SL-11C+L-10 ${ }^{7}$ & $\begin{array}{l}\text { Manual cleaning of external surfaces, including external surface } \\
\text { of couplings, by rubbing with cleaning wipes (ICA Städservett, } \\
\text { ICA, Solna, Sweden) until visibly clean for } \geq 12 \mathrm{~s} \text {. }\end{array}$ \\
\hline 5 & Head support & $\begin{array}{l}\text { Standard washing } \\
\text { liquid+ SL-11C+L-10 }\end{array}$ & $\begin{array}{l}\text { Dismantling of } \mathrm{SH} \text {, manual cleaning with a brush } \\
\text { (below the water surface) of } \mathrm{SH} \text { shell and shaft in } \\
\text { warm water until visibly clean for } \geq 30 \mathrm{~s} \text {. } \\
\text { Rinsing in lukewarm-to-warm water and rubbing with } \\
\text { a cleaning wipe until visibly clean for } \geq 12 \mathrm{~s} \text {. } \\
\text { Rubbing with cleaning wipes until visibly clean, for } \geq 15 \mathrm{~s} \text {. } \\
\text { Followed by spraying a surface disinfectant (Dax } 75+, \\
\text { KiiltoClean AB, Täby, Sweden or LiV72+, Clemondo, } \\
\text { Helsingborg, Sweden) and rubbing the surface for } \geq 25 \mathrm{~s} \text { until } \\
\text { dry and thereafter spraying surface disinfectant and left to } \\
\text { air-dry. }\end{array}$ \\
\hline
\end{tabular}

1. Low-speed handpiece, ${ }^{2}$. Surgical low-speed handpiece, ${ }^{3}$. High-speed handpiece, ${ }^{4}$. Laurylamine Dipropylenediamine, ${ }^{5 .}$ Ethanol, propanol, and tensed, ${ }^{6}$. Ethanol, isopropanol, and tensed, and ${ }^{7}$. Sodium Laureth-11 Carboxylate and Laureth-10.

\subsection{Bacteriological Analyses}

All 3M Swab Samplers and dip slides were taken to the laboratory at the Swedish University of Agricultural Sciences on the day of sampling. $3 \mathrm{M}^{\mathrm{TM}}$ Swab Samplers were vortexed and $1 \mathrm{~mL}$ broth was drawn from the sampling tube and put onto a 3M Petrifilm TM aerobic count (AC) Plate (3M Petrifilm ${ }^{\mathrm{TM}}$ Aerobic Count Plate, Saint Paul, Minnesota, 
USA), see Figure S1: Petrifilm ${ }^{\mathrm{TM}}$ negative control, as further described in the $3 \mathrm{M}^{\mathrm{TM}}$ Swab Sampler Method [21]. Samples were incubated aerobically in $30 \pm 1^{\circ} \mathrm{C}$ for $48 \pm 2 \mathrm{~h}$. Dip slides were incubated in $37 \pm 1{ }^{\circ} \mathrm{C}$ for $48 \pm 2 \mathrm{~h}$. The colonies were counted manually by the first author, as described in the interpretation guide [23]. All 3M Petrifilm ${ }^{\mathrm{TM}}$ AC Plates and dip slides were photographed for documentation.

\subsection{Data Management}

Microsoft ${ }^{\circledR}$ Excel ${ }^{\circledR} 2016$ (16.0.5134.1000) (Microsoft Corporation, Redmond, Washington, USA) was used for data management and descriptive statistics.

\section{Results}

The study included 80 samples from handpieces, 42 samples from dummies, 24 samples from the head support, and two negative controls using $3 \mathrm{M}^{\mathrm{TM}}$ Swab Samplers. In addition, dip slides were used in 14 samples from the head support and for two negative controls. No bacterial growth was detected in the samples from negative controls.

\subsection{Handpieces}

Bacterial growth was detected in all samples from $\mathrm{HSH}$, both after dental procedures and after cleaning or disinfecting (see Table 4). In all samples from external surfaces from LSH and $\mathrm{SH}$, bacterial growth was found after dental procedures, and after cleaning or disinfecting bacterial growth was still detected in all but one sample. After dental procedures, bacterial growth was detected in all samples from the coupling of LSH and in 6 of 10 samples from the shaft in SH. After cleaning or disinfecting, no bacterial growth was found in couplings from LSH while bacterial growth was found in 2 of 10 samples from the shaft of SH.

Table 4. Bacterial load of external surfaces, couplings, and the shaft of handpieces after dental procedures and after cleaning or disinfecting. Colony forming units (CFU) is given in total CFU/external surface, $\mathrm{CFU} /$ coupling and inner piece, respectively. Pulp exposure is divided into the categories: no exposure, risk for exposure, exposure, and not applicable. The difference between risk for exposure and exposure is that risk for exposure includes dental procedures when the pulp exposure is unintended and exposure includes dental procedures when pulp exposure is intended.

\begin{tabular}{|c|c|c|c|c|c|c|}
\hline $\begin{array}{l}\text { Cleaning or } \\
\text { Disinfecting } \\
\text { Substance }\end{array}$ & $\begin{array}{c}\text { Type of } \\
\text { Handpiece }\end{array}$ & Pulp Exposure & $\begin{array}{l}\text { CFU after } \\
\text { Dental } \\
\text { Procedure, } \\
\text { External } \\
\text { Surface }\end{array}$ & $\begin{array}{l}\text { CFU after } \\
\text { Cleaning or } \\
\text { Disinfecting, } \\
\text { External } \\
\text { Surface }\end{array}$ & $\begin{array}{c}\text { CFU after } \\
\text { Dental } \\
\text { Procedure, } \\
\text { Coupling or } \\
\text { Shaft }\end{array}$ & $\begin{array}{c}\text { CFU after } \\
\text { Cleaning or } \\
\text { Disinfecting, } \\
\text { Coupling or } \\
\text { Shaft }\end{array}$ \\
\hline $\mathrm{LD}^{1}$ & $\mathrm{SH}^{3}$ & NA & NA & $4^{7}$ & NA & $0^{7}$ \\
\hline LD & $\mathrm{LSH}^{4}$ & NA & NA & $8^{7}$ & NA & $0^{7}$ \\
\hline LD & $\mathrm{HSH}^{5}$ & NA & NA & $3^{7}$ & NA & $3^{7}$ \\
\hline LD & $\mathrm{SH}$ & No exposure & TNTC $^{6}$ & 1 & 0 & 1 \\
\hline LD & $\mathrm{SH}$ & No exposure & TNTC & 28 & 0 & 0 \\
\hline LD & $\mathrm{SH}$ & $\begin{array}{l}\text { Risk for } \\
\text { exposure }\end{array}$ & 620 & 0 & 2 & 0 \\
\hline LD & LSH & $\begin{array}{l}\text { Risk for } \\
\text { exposure }\end{array}$ & 510 & 1 & 26 & 0 \\
\hline LD & $\mathrm{HSH}$ & $\begin{array}{l}\text { Risk for } \\
\text { exposure }\end{array}$ & 820 & 1420 & TNTC & 10 \\
\hline LD & $\mathrm{SH}$ & $\begin{array}{l}\text { Risk for } \\
\text { exposure }\end{array}$ & TNTC & 8 & 1 & 0 \\
\hline LD & LSH & $\begin{array}{l}\text { Risk for } \\
\text { exposure }\end{array}$ & 420 & 1260 & 20 & 0 \\
\hline LD & $\mathrm{HSH}$ & $\begin{array}{l}\text { Risk for } \\
\text { exposure }\end{array}$ & 720 & 70 & TNTC & 520 \\
\hline LD & $\mathrm{SH}$ & No exposure & TNTC & 5 & 1 & 0 \\
\hline
\end{tabular}


Table 4. Cont.

\begin{tabular}{|c|c|c|c|c|c|c|}
\hline $\begin{array}{l}\text { Cleaning or } \\
\text { Disinfecting } \\
\text { Substance }\end{array}$ & $\begin{array}{c}\text { Type of } \\
\text { Handpiece }\end{array}$ & Pulp Exposure & $\begin{array}{c}\text { CFU after } \\
\text { Dental } \\
\text { Procedure, } \\
\text { External } \\
\text { Surface }\end{array}$ & $\begin{array}{l}\text { CFU after } \\
\text { Cleaning or } \\
\text { Disinfecting, } \\
\text { External } \\
\text { Surface }\end{array}$ & $\begin{array}{c}\text { CFU after } \\
\text { Dental } \\
\text { Procedure, } \\
\text { Coupling or } \\
\text { Shaft }\end{array}$ & $\begin{array}{c}\text { CFU after } \\
\text { Cleaning or } \\
\text { Disinfecting, } \\
\text { Coupling or } \\
\text { Shaft }\end{array}$ \\
\hline SL-11C+L-10 ${ }^{2}$ & $\mathrm{SH}$ & NA & NA & $69^{7}$ & NA & $0^{7}$ \\
\hline SL-11C+L-10 & LSH & NA & NA & TNTC $^{7}$ & NA & $0^{7}$ \\
\hline SL-11C+L-10 & $\mathrm{HSH}$ & NA & NA & $10^{7}$ & NA & $8^{7}$ \\
\hline SL-11C+L-10 & $\mathrm{SH}$ & $\begin{array}{l}\text { Risk for } \\
\text { exposure }\end{array}$ & TNTC & TNTC & 5 & 0 \\
\hline SL-11C+L-10 & LSH & $\begin{array}{l}\text { Risk for } \\
\text { exposure }\end{array}$ & TNTC & 231 & 88 & 0 \\
\hline SL-11C+L-10 & $\mathrm{HSH}$ & $\begin{array}{l}\text { Risk for } \\
\text { exposure }\end{array}$ & TNTC & TNTC & TNTC & TNTC \\
\hline SL-11C+L-10 & $\mathrm{SH}$ & No exposure & TNTC & 160 & 14 & 30 \\
\hline SL-11C+L-10 & $\mathrm{SH}$ & No exposure & TNTC & TNTC & 4 & 0 \\
\hline SL-11C+L-10 & $\mathrm{SH}$ & $\begin{array}{l}\text { Risk for } \\
\text { exposure }\end{array}$ & TNTC & 25 & 0 & 0 \\
\hline SL-11C+L-10 & LSH & $\begin{array}{l}\text { Risk for } \\
\text { exposure }\end{array}$ & TNTC & 900 & 520 & 0 \\
\hline SL-11C+L-10 & $\mathrm{SH}$ & No exposure & TNTC & 1350 & 0 & 0 \\
\hline
\end{tabular}

1. Laurylamine Dipropylenediamine, ${ }^{2}$. Sodium Laureth-11 Carboxylate and Laureth-10, ${ }^{3}$. Surgical low-speed handpiece, ${ }^{4}$. Low-speed handpiece, ${ }^{5}$. High-speed handpiece, ${ }^{6}$ Too numerous to count, and ${ }^{7}$. Samples taken before the first patient of the day.

\subsection{Dummies}

Bacterial growth was detected in all samples from external surfaces of dummies before the first patient of the day and in 11 of 12 samples from the external surface of dummies after dental procedures compared to 5 of 11 after cleaning or disinfection (see Table 5). In 2 of 3 samples from couplings of dummies, bacterial growth was detected before the first patient of the day. In addition, bacterial growth was detected in 2 of 11 samples from the coupling of dummies after cleaning or disinfecting.

Table 5. Bacterial load of dummies (handpieces not used during dental procedure, illustrating extra handpieces placed close by (approximately $70 \mathrm{~cm}$ from the patient's oral cavity) if needed during the procedure. Day 1 dummy 1 was put in place approximately $10 \mathrm{~min}$ before the first patient of the day, day 2 dummies 1 and 2 were put in place approximately $10 \mathrm{~min}$ before the first patient of the day. Dummy 1 was sampled and cleaned or disinfected after each patient whilst dummy 2 was not cleaned or disinfected, and sampled only after the last patient included for the day. CFU is given in total CFU/external surface and CFU/coupling respectively.

\begin{tabular}{|c|c|c|c|c|}
\hline Dummy & $\begin{array}{l}\text { Cleaning or Disinfection } \\
\text { Substance }\end{array}$ & $\begin{array}{c}\text { CFU after Dental Procedure, } \\
\text { External Surface }\end{array}$ & $\begin{array}{c}\text { CFU after Cleaning or } \\
\text { Disinfection, External Surface }\end{array}$ & $\begin{array}{l}\text { CFU after Cleaning or } \\
\text { Disinfection, Couplings }\end{array}$ \\
\hline 1 & NA & NA & $183^{3}$ & $22^{3}$ \\
\hline 1 & $\mathrm{LD}^{1}$ & TNTC & 1 & 0 \\
\hline 1 & LD & 1340 & 18 & 3 \\
\hline 1 & LD & 0 & 0 & 0 \\
\hline 1 & LD & 67 & 0 & 0 \\
\hline 1 & LD & 82 & 0 & 0 \\
\hline 1 & LD & 1100 & 8 & 0 \\
\hline 1 & LD & NA & $440^{3}$ & $1^{3}$ \\
\hline 2 & NA & NA & $267^{3}$ & $0^{3}$ \\
\hline 1 & SL-11C+L-10 2 & TNTC & 0 & 0 \\
\hline 1 & SL-11C+L-10 & 330 & 2 & 1 \\
\hline 1 & SL-11C+L-10 & 87 & 1 & 0 \\
\hline 1 & SL-11C+L-10 & 18 & 0 & 0 \\
\hline 1 & SL-11C+L-10 & 35 & 0 & 0 \\
\hline 2 & NA & TNTC & NA & NA \\
\hline
\end{tabular}

\footnotetext{
${ }^{1 .}$ Laurylamine Dipropylenediamine, ${ }^{2}$ Sodium Laureth-11 Carboxylate and Laureth-10, and ${ }^{3}$. Samples taken before the first patient of the day.
} 


\subsection{Head Support}

In both samples from the head support before the first patient of the day bacterial growth was detected, and in one of them the $\mathrm{CFU} / \mathrm{cm}^{2}$ were too numerous to count. The bacterial load detected on the head support was high (usually too numerous to count) after dental procedures. Both cleaning and/or disinfection reduced the bacterial load as seen in most of the samples (see Table 6).

Table 6. Bacterial load detected on the head support after dental procedures, and after cleaning and/or disinfecting. Colony forming units (CFU) are given in CFU $/ \mathrm{cm}^{2}$. For bacteriological analyses $3 \mathrm{M}$ Petrifilm ${ }^{\mathrm{TM}}$ aerobic count (AC) Plates and dip slides with TSA agar/TSA agar with a neutralizer, neutralizing several disinfectants.

\begin{tabular}{|c|c|c|c|c|c|c|}
\hline \multirow[t]{2}{*}{$\begin{array}{l}\text { Cleaning and } \\
\text { Disinfecting } \\
\text { Substances }\end{array}$} & \multicolumn{3}{|c|}{ Bacterial Load after Dental Procedure } & \multicolumn{3}{|c|}{$\begin{array}{l}\text { Bacterial Load after Cleaning } \\
\text { and/or Disinfecting }\end{array}$} \\
\hline & Petrifilm $^{\mathrm{TM}}$ & $\begin{array}{l}\text { Dip Slide TSA } \\
+ \text { Neutralizer }\end{array}$ & Dip Slide TSA & Petrifilm $^{\mathrm{TM}}$ & $\begin{array}{l}\text { Dip Slide TSA } \\
\text { + Neutralizer }\end{array}$ & Dip Slide TSA \\
\hline $\mathrm{LD}^{1}+\mathrm{EPT}^{2} / \mathrm{LD}+\mathrm{EIT}^{3}$ & NA & NA & NA & $0.03^{5}$ & $0.11^{5}$ & $0^{5}$ \\
\hline LD+EPT/LD+EIT & TNTC & 7.23 & TNTC & 3 & 0.11 & 0.96 \\
\hline LD+EPT/LD+EIT & TNTC & TNTC & TNTC & 0.04 & 0.11 & 0 \\
\hline $\mathrm{LD}+\mathrm{EPT} / \mathrm{LD}+\mathrm{EIT}$ & TNTC & TNTC & TNTC & 0.07 & 0 & 0 \\
\hline LD+EPT/LD+EIT & TNTC & 5.32 & 9.89 & 0.06 & 0 & 0.11 \\
\hline $\mathrm{LD}+\mathrm{EPT} / \mathrm{LD}+\mathrm{EIT}$ & TNTC & 1.49 & 6.38 & 0 & 0 & 0 \\
\hline $\mathrm{LD}+\mathrm{EPT} / \mathrm{LD}+\mathrm{EIT}$ & TNTC & TNTC & TNTC & 0.01 & 0 & 0.85 \\
\hline $\begin{array}{c}\mathrm{SL}-11 \mathrm{C}+\mathrm{L}-10^{4}+ \\
\mathrm{EPT} / \mathrm{EIT}\end{array}$ & NA & NA & NA & TNTC $^{5}$ & NA & NA \\
\hline $\begin{array}{l}\text { SL-11C+L-10 + } \\
\text { EPT } / \text { EIT }\end{array}$ & TNTC & NA & NA & 1.45 & NA & NA \\
\hline $\begin{array}{l}\text { SL-11C+L-10 + } \\
\text { EPT } / \text { EIT }\end{array}$ & TNTC & NA & NA & 0.10 & NA & NA \\
\hline $\begin{array}{l}\text { SL-11C+L-10 + } \\
\text { EPT } / \text { EIT }\end{array}$ & TNTC & NA & NA & TNTC & NA & NA \\
\hline $\begin{array}{l}\text { SL-11C+L-10 + } \\
\text { EPT } / \text { EIT }\end{array}$ & TNTC & NA & NA & 0 & NA & NA \\
\hline $\begin{array}{l}\text { SL-11C+L-10 + } \\
\text { EPT } / \text { EIT }\end{array}$ & TNTC & NA & NA & 0.73 & NA & NA \\
\hline
\end{tabular}

${ }^{1 .}$ Laurylamine Dipropylenediamine, ${ }^{2 .}$ Ethanol, propanol and tensid, ${ }^{3 \cdot}$ Ethanol, isopropanol and tensid, ${ }^{4}$. Sodium Laureth-11 Carboxylate and Laureth-10, and ${ }^{5}$. Samples taken before the first patient of the day.

\section{Discussion}

To the best of our knowledge, this is the first study of hygiene in equine dentistry. According to Swedish guidelines in human dentistry, all handpieces should meet criteria for high-level disinfected equipment, and handpieces used for surgical procedures should be sterile $[9,15,16]$. In equine dentistry, the risks of spreading blood-borne diseases, such as those that are important in human dentistry $[8,24]$, are not seen as a major risk. In equine dentistry there are, however, risks of spreading various pathogenic and resistant microorganisms [1]. According to the Swedish guidelines on IPC in equine healthcare, dental equipment that comes in contact with mucus membranes, but not penetrating sterile tissue, shall meet criteria for high-level disinfected equipment and surgical dental equipment shall be sterile [10]. According to the American Animal Hospital Associations' dental care guidelines for dogs and cats, all dental instruments shall be cleaned and sterilized after each use [25] whilst World Small Animal Veterinary Association guidelines states all dental equipment shall be cleaned, disinfected, and/or sterilized based on the equipment's intended use [26] Also small animal dentistry literature recommends semicritical and critical instruments to be sterilized after each use [11]. All the recommendations are brief and reflect hygiene recommendations in human dentistry and the differences in guidelines on how to clean, disinfect, and sterilize dental equipment reflects the differences found between countries in human dentistry. All these recommendations are very brief and no clear criteria is given for handpieces. It is important to take into account both the differences and the similarities in risks between human and equine dentistry and to 
have knowledge of, e.g., the microbial contamination in equine dentistry when developing guidelines on IPC measures in equine dentistry. In this study, equipment and the close patient environment were highly contaminated after dental procedures. The bacterial load in the immediate environment was lower after cleaning and/or disinfecting, but handpieces did not meet the criteria for high-level disinfected equipment after cleaning or disinfecting.

It can be assumed that a high bacterial load is an indicator of the presence of potentially pathogenic microorganisms. In a study by Adams et al. [27] investigating the occurrence of Staphylococcus aureus in a human intensive care unit, most Staphylococcus aureus were detected on heavily contaminated hand-touch sites. This study has shown that dental procedures, using handpieces, contaminate the equipment and the surrounding environment, with a potentially increased risk of transmission of pathogens between patients, staff, and facilities. As HSH is used for endodontic treatment, transmission of microorganisms can have severe consequences since the pulp is exposed, i.e., there is an increased risk for infection. To classify HSH as critical equipment could emphasize its importance to improve IPC measures in equine dentistry. For semi-critical equipment as $\mathrm{LSH}$ and $\mathrm{SH}$, when not used for endodontic treatment, it can be discussed whether the strictest definition of high-level disinfected equipment is needed in equine dentistry. An important factor for considering to use the less strict definition of high-level disinfected equipment (i.e., free from pathogens and occurrence of occasional vital microorganisms, see Table 1) for semi-critical LSH and SH is that it is important to identify an achievable, and measurable, threshold value for manual cleaning and disinfection. It is difficult to estimate the risk of infection transmission if the less strict Swedish definition of high-level disinfected equipment would be applied for handpieces. The results of our study indicate that even the less strict criterion may require more meticulous routines for cleaning and disinfection.

In this study, the effect of surface disinfection of handpieces was similar to the results reported by Pinto et al. [12] in a study in human dentistry, where handpieces did not meet even the less strict criteria for high-level disinfected equipment in human dentistry [9]. The couplings in both LSH and HSH can be regarded as a bridge between external and internal surfaces. The couplings can, if the IPC measures are ineffective, serve as a vector spreading infectious agents between patients. Infectious agents may occur in horses without clinical symptoms of infection, for example, Pusterla et al. [1] reported respiratory pathogens in $22 \%$ of healthy horses submitted for routine dental care.

If the upper limit for bacterial load on external contact surfaces of $2.5 \mathrm{CFU} / \mathrm{cm}^{2}$, as suggested in studies on human hospital cleanliness [28-31], is used as the limit of acceptance for the head support (a non-critical piece of equipment), most samples in this study meet the criteria after cleaning and/or disinfecting.

Limits of the study: The bacterial load on the shaft of the SH after dental procedures in this study diverges from results reported by Smith et al. [3], in median $1000 \mathrm{CFU} /$ surgical gear compared to up to $30 \mathrm{CFU} /$ shaft in this study. Smith et al. [3] sampled the surgical gear which can be assumed to be more highly contaminated compared to the shaft sampled in this study. Smith et al. [3] also used a better sampling method and a culturing method enabling identification of a wider range of bacteria. If the surgical gear would have been sampled in this study using the same method as Smith et al. [3], it can be assumed the bacterial load would have been considerably higher. Petrifilms ${ }^{\mathrm{TM}}$ were incubated in $30 \pm 1{ }^{\circ} \mathrm{C}$ which means environmental flora is probably dominating and potential pathogenic bacteria may have been overgrown. The amount of potential pathogen bacteria would probably have been more accurate if Petrifilms ${ }^{\mathrm{TM}}$ had been incubated in $37 \pm{ }^{\circ} \mathrm{C}$, which is optimal for most mammalian pathogens [32]. Data on length of time in contact with dental tissue was not collected; this data could possibly have provided important information about the degree of contamination after different lengths of time in contact with dental tissue. 
More research will be needed to evaluate how manual cleaning followed by chemical disinfecting of external and internal surfaces of handpieces can result in the less strict Swedish definition of high-level disinfected handpieces, i.e., free from pathogens and occurrence of occasional vital microorganisms. Other topics for future research should be to develop evidence-based guidelines by (1) design and test IPC routines for equine dental procedures and (2) investigate what level of hygiene is needed to minimize the risk of transmission of infectious agents between patients in equine dentistry.

High contamination of the equipment and the close patient environment, combined with handpieces not meeting criteria for high-level disinfected equipment after manual cleaning or disinfecting, indicates an urgent need for evidence-based guidelines on hygiene in equine dentistry. Based on the study results, protocols for assessment of contamination level could be developed. Larger series of data from several clinics as well as mobile practice should be collected as a basis for such guidelines. Categorization of dental equipment as critical, semi-critical, and non-critical equipment, and a clear definition of hygiene criteria for such equipment are also needed. In addition, guidelines on how to clean, disinfect, and, in some cases, sterilize dental equipment are necessary. Methods for monitoring each step are also needed.

\section{Conclusions}

The detected bacterial load on the equipment and in the close patient environment was often high after dental procedures. Handpieces did not meet the criteria for highlevel disinfected equipment after cleaning or disinfecting. In most cases cleaning and/or disinfecting of the head support resulted in a lowered bacterial load. This implies there is a need for evidence-based guidelines on IPC procedures for equine dentistry. In addition, data to support appropriate threshold levels are needed.

Supplementary Materials: The following are available online at https:/ /www.mdpi.com/article/10 .3390 / ani11082320/s1, Figure S1: Petrifilm ${ }^{\mathrm{TM}}$ negative control, Table S1: Bacterial load pilot study, and Table S2: Sampling methods tested.

Author Contributions: The authors have contributed to the following sections of this work: Conceptualization, T.A.-J., A.P.; methodology, T.A.-J., A.P., K.B., S.S.-L., J.P., and A.B.; formal analysis, T.A.-J.; investigation, T.A.-J., A.P.; data curation, T.A.-J.; writing—original draft preparation, T.A.-J.; writingreview and editing, T.A.-J., A.P., K.B., S.S.-L., J.P., and A.B.; visualization, T.A.-J.; supervision, K.B., S.S.-L., J.P., and A.B.; project administration, T.A.-J.; funding acquisition, T.A.-J., J.P. All authors have read and agreed to the published version of the manuscript.

Funding: This research was funded by Gymn. dir Stina Johansson i Fränsta Scholarship for research in veterinary medicine, Swedish University of Agricultural Sciences.

Institutional Review Board Statement: Not applicable. As only equipment was sampled and no human or animal data were collected, seeking ethical permit was not relevant and could, under Swedish legislation, not be obtained. The participating clinics were assured anonymity.

Acknowledgments: The authors wish to acknowledge the clinics who provided the sampling environments.

Conflicts of Interest: The authors declare no conflict of interest.

\section{References}

1. Pusterla, N.; Rice, M.; Henry, T.; Barnum, S.; James, K. Investigation of the Shedding of Selected Respiratory Pathogens in Healthy Horses Presented for Routine Dental Care. J. Vet. Dent. 2020, 37, 88-93. [CrossRef]

2. Lewis, D.L.; Boe, R.K. Cross-infection risks associated with current procedures for using high-speed dental handpieces. J. Clin. Microbiol. 1992, 30, 401-406. [CrossRef]

3. Smith, G.; Smith, A. Microbial contamination of used dental handpieces. Am. J. Infect. Control. 2014, 42, 1019-1021. [CrossRef] [PubMed]

4. Murali, S.; Madhulaxmi, M.; Muthuseka, M.R. To Evaluate Bacterial Contamination of Surgical Handpiece Used in Minor Oral Surgical Procedures in Dentistry. J. Evol. Med Dent. Sci. 2020, 9, 3463. [CrossRef] 
5. Herd, S.; Chin, J.; Palenik, C.J.; Ofner, S. The in vivo contamination of air-driven low-speed handpieces with prophylaxis angles. J. Am. Dent. Assoc. 2007, 138, 1360-1365. [CrossRef]

6. Innes, N.; Johnson, I.; Al-Yaseen, W.; Harris, R.; Jones, R.; Kc, S.; McGregor, S.; Robertson, M.; Wade, W.; Gallagher, J. A systematic review of droplet and aerosol generation in dentistry. J. Dent. 2021, 105, 103556-103556. [CrossRef] [PubMed]

7. Ionescu, A.; Cagetti, M.G.; Ferracane, J.L.; Garcia-Godoy, F.; Brambilla, E. Topographic aspects of airborne contamination caused by the use of dental handpieces in the operative environment. J. Am. Dent. Assoc. 2020, 151, 660-667. [CrossRef] [PubMed]

8. Kohn, W.G.; Collins, A.S.; Cleveland, J.L.; Harte, J.A.; Eklund, K.J.; Malvitz, D.M. Guidelines for infection control in dental health-care settings-2003. MMWR. Recomm. Rep. 2003, 52, 1-61.

9. Andersson, Y.; Bolle, A.-C.; Göransson, Å.; Jakobsson, C.; Skott, P.; Spencer, I. Riktlinjer för Vårdhygien Inom Svensk Tandvård [Guidelines for Infection Prevention and Control in Swedish Dentistry]. Available online: https://s3-eu-west-1.amazonaws.com/ static.wm3.se/sites/16/media/281961_HOBIT_final_version_f\%C3\%B6r_publicering.pdf?1556447135 (accessed on 24 March 2021).

10. The Swedish Veterinary Association and the Equine Section of the Committee for Veterinary Medicine. Infektionskontroll Inom Hästsjukvård [Infection Prevention and Control in Equine Healthcare]. Available online: https://svf.se/media/10mbpucp/ infektionskontroll_inom_hastsjukvard.pdf (accessed on 28 June 2021).

11. Terpak, C.H.; Verstraete, F.J.M. Instrumentation, Patient positioning, and aseptic technique. In Oral and Maxillofacial Surgery in Dogs and Cats; Verstraete, F.J.M., Lomer, M.J., Eds.; Saunders Elsvier: St. Louis, MO, USA, 2012; pp. 55-68.

12. Pinto, F.M.G.; Bruna, C.Q.D.M.; Camargo, T.C.; Marques, M.; Silva, C.B.; Sasagawa, S.M.; Mimica, L.M.J.; Graziano, K.U. The practice of disinfection of high-speed handpieces with 70\% w/v alcohol: An evaluation. Am. J. Infect. Control. 2017, 45, e19-e22. [CrossRef]

13. Offner, D.; Brisset, L.; Musset, A.-M. Evaluation of the mechanical cleaning efficacy of dental handpieces. J. Hosp. Infect. 2019, 103, e73-e80. [CrossRef] [PubMed]

14. Winter, S.; Smith, A.; Lappin, D.; McDonagh, G.; Kirk, B. Failure of non-vacuum steam sterilization processes for dental handpieces. J. Hosp. Infect. 2017, 97, 343-347. [CrossRef]

15. Welfare, N.B.O.H.A. Att Förebygga Vårdrelaterade Infektioner -ett Kunskapsunderlag [To Prevent Healthcare Associated Infections-A Basis of Knowledge]; Bergslagens Grafiska: Lindesberg, Sweden, 2006; pp. 304-305.

16. Swedish Standards Institute (SIS). SS-EN 556-1/AC. Sterilisering av Medicintekniska Produkter-Krav för Märkning Med Symbolen "STERILE"—Del 1: Krav för Medicinska Produkter i Sluten Förpackning [Sterilization of Medical Devices—Requirements for Medical Devices to be Designated 'STERILE'_Part 1: Requirements for Terminally Sterilized Medical Devices]; Swedish Standards Institute: Stockholm, Sweden, 2006.

17. European Veterinary Dental College. E.V.D. Equine Training Programmes \& Credentialing. Available online: https://www.evdc.org/ resources/media/Documents/How_to_become_a_resident/EVDC_Equine_Training_and_Credential_Document.pdf (accessed on 24 March 2021).

18. Lundström, T. (Djurtandvårdskliniken, Söderköping, Sweden). Personal communication, 2021.

19. McDonnell, G.; Burke, P. Disinfection: Is it time to reconsider Spaulding? J. Hosp. Infect. 2011, 78, 163-170. [CrossRef] [PubMed]

20. Tessi, M.A.; Aríngoli, E.E.; Pirovani, M.E.; Vincenzini, A.Z.; Sabbag, N.G.; Costa, S.C.; García, C.C.; Zannier, M.S.; Silva, E.R.; Moguilevsky, M.A. Microbiological Quality and Safety of Ready-To-Eat Cooked Foods from a Centralized School Kitchen in Argentina. J. Food Prot. 2002, 65, 636-642. [CrossRef] [PubMed]

21. 3M. Petrifilm Environmental Monitoring Procedures. Available online: https://multimedia.3m.com/mws/media/241111O/ environmental-monitoring-procedures-article.pdf (accessed on 15 February 2021).

22. Maertens, H.; De Reu, K.; Van Weyenberg, S.; Van Coillie, E.; Meyer, E.; Van Meirhaeghe, H.; Van Immerseel, F.; Vandenbroucke, V.; Vanrobaeys, M.; Dewulf, J. Evaluation of the hygienogram scores and related data obtained after cleaning and disinfection of poultry houses in Flanders during the period 2007 to 2014. Poult. Sci. 2018, 97, 620-627. [CrossRef] [PubMed]

23. 3M. Interpretation Guide. Available online: https://multimedia.3m.com/mws/media/236194O/petrifilm-aerobic-interpretationguide.pdf (accessed on 24 May 2021).

24. Edwardsson, S.; Bäckman, N. Smittrisker Och Hygien i Tandvården [Risk of Infection and Hygiene in Dentistry]. Available online: http:/ / static.wm3.se/sites/16/media/5627_Smittrisker_och_hygien_i_tandva_u030Arden_120926.pdf?1396533033 (accessed on 24 June 2021).

25. Bellows, J.; Berg, M.L.; Dennis, S.; Harvey, R.; Lobprise, H.B.; Snyder, C.J.; Stone, A.E.; Van De Wetering, A.G. 2019 AAHA Dental Care Guidelines for Dogs and Cats. J. Am. Anim. Hosp. Assoc. 2019, 55, 49-69. [CrossRef]

26. Niemiec, B.; Gawor, J.; Nemec, A.; Clarke, D.; McLeod, K.; Tutt, C.; Gioso, M.; Steagall, P.; Chandler, M.; Morgenegg, G.; et al. World Small Animal Veterinary Association Global Dental Guidelines. J. Small Anim. Pr. 2020, 61, E36-E161. [CrossRef]

27. Adams, C.E.; Dancer, S.J. Dynamic Transmission of Staphylococcus Aureus in the Intensive Care Unit. Int. J. Environ. Res. Public Health 2020, 17, 2109. [CrossRef]

28. Griffith, C.; Cooper, R.; Gilmore, J.; Davies, C.; Lewis, M. An evaluation of hospital cleaning regimes and standards. J. Hosp. Infect. 2000, 45, 19-28. [CrossRef] [PubMed]

29. Lewis, T.; Griffith, C.; Gallo, M.; Weinbren, M. A modified ATP benchmark for evaluating the cleaning of some hospital environmental surfaces. J. Hosp. Infect. 2008, 69, 156-163. [CrossRef] 
30. Pasquarella, C.; Veronesi, L.; Napoli, C.; Castiglia, P.; Liguori, G.; Rizzetto, R.; Torre, I.; Righi, E.; Farruggia, P.; Tesauro, M.; et al. Microbial environmental contamination in Italian dental clinics: A multicenter study yielding recommendations for standardized sampling methods and threshold values. Sci. Total Environ. 2012, 420, 289-299. [CrossRef]

31. Mulvey, D.; Redding, P.; Robertson, C.; Woodall, C.; Kingsmore, P.; Bedwell, D.; Dancer, S. Finding a benchmark for monitoring hospital cleanliness. J. Hosp. Infect. 2011, 77, 25-30. [CrossRef] [PubMed]

32. Quinn, P.J.; Markey, B.K.; Leonard, F.C.; FitzPatrick, E.S.; Fanning, S.; Hartigan, P.J. Veterinary Microbiology and Microbial Disease, 2nd ed.; Blackwell Publishing Ltd.: Hoboken, NJ, USA, 2011; p. 211. 